\title{
OPTIMIZATION OF $\mathrm{PO}_{4}{ }^{2-}$ AND $\mathrm{NO}_{3}{ }^{2-}$ CONCENTRATION IN BENTHIC EPILITHIC DIATOM CULTURES AS BIOLOGICAL INDICATORS IN PREDICTING THE TROPHIC STATUS OF THE SWARTPRUIT RIVER, SOUTH AFRICA
}

\author{
Nnabuo-Eguzozie, E. C. ${ }^{1}$ - Atagana, H. I. ${ }^{2}$ - AdEleKe, R. ${ }^{3}$ - EguZOZIE, K. U. ${ }^{4 *}$ \\ ${ }^{1}$ University of South Africa "Florida Campus" College of Agriculture and Environmental \\ Sciences, Department of Environmental Sciences, Florida 1709, Johannesburg, South Africa \\ (phone: +27-114-713-296) \\ ${ }^{2}$ University of South Africa "Muckleneuk Campus" College of Graduate Studies, Institute for \\ Science and Technology Education, Pretoria 0002, South Africa \\ (phone: +27-822-009-855) \\ ${ }^{3}$ Agricultural Research Council "Microbiology and Environmental Biotechnology Research \\ Group”, Institute for Soil, Climate and Water, Agricultural Research Council, Pretoria Office, \\ Pretoria 0001, South Africa \\ (phone: +27-728-843-243) \\ ${ }^{4}$ University of Johannesburg “Doornfontein Campus” Faculty of Science, Department of \\ Applied Chemistry”, Doornfontein 2028, Johannesburg, South Africa \\ (phone: +27-115-596-456) \\ *Corresponding author \\ e-mail: eguzoziekennedy@yahoo.co.uk; phone: +27-638-270-297; fax: +27-11-559-6425
}

(Received 30 $0^{\text {th }}$ Apr 2020; accepted $11^{\text {th }}$ Aug 2020)

\begin{abstract}
A study probing the optimization of $\mathrm{PO}_{4}{ }^{2-}$ and $\mathrm{NO}_{3}{ }^{2-}$ concentrations in benthic epilithic diatom cultures as biological indicators in predicting the trophic status and water quality conditions of the Swartpruit River was undertaken. Diatom materials were collected from November 2014 - February 2015 from the river and cultivated in an optimized growth medium with $0.003,0.005,0.01,0.015,0.2,0.025$, $0.05,0.1,0.15,0.2, .025,0.3,0.4 \mathrm{mg} / \mathrm{L} \mathrm{PO}_{4}{ }^{2-}$ and $0.1,0.3,0.5,1.0,2.0,2.5,5.0,7.0,9.0,10,12,13 \mathrm{mg} / \mathrm{L}$ $\mathrm{NO}_{3}{ }^{2-}$ ) amounts, respectively. The results revealed that optimization of $\mathrm{PO}_{4}{ }^{2-}$ and $\mathrm{NO}_{3}{ }^{2-}$ concentrations in the growth media encouraged corresponding fluctuations in the taxonomic profiles and abundance of diatom assemblage cultures and was plausibly applied in determining the trophic status and water quality condition of the river. Principal component analysis was used to evaluate the relationship between diatom diversity and optimized phosphate and nitrate concentrations in an ordination biplot revealed $45.62 \%$ and $37.93 \%$ variations in the data. We anticipate that the methodology and data analysis presented in this report could be applied in predicting the trophic status and water quality of any inland freshwater resource like the Swartspruit River, which undergoes seasonal harmful algal bloom.

Keywords: diatom assemblages, water quality, harmful algal bloom, taxonomic profiles, inland freshwater resource
\end{abstract}

\section{Introduction}

Diatoms are pivotal in the food web and have a tight link to biochemical fundamental processes like photosynthesis and respiration in aquatic environments (Wong, 2014; Torres et al., 2014; Barinova et al., 2019; Zhang et al., 2020). They are important primary producers and represent an important source of food for aquatic grazing organisms (Maria et al., 2011; Estifanos et al., 2013; Shinneman et al., 2016; Trobaja and Mann, 2019). 
Diatoms occupy a unique niche in the aquatic ecosystem, requiring nutrients for growth and reproduction (Dong et al., 2012; Muhid et al., 2013; Barinova et al., 2019). They are widely diverse and abundant in the freshwater environments as some species might require different nutrient compositions from others (Lynn et al., 2000; Taylor et al., 2007; Kociolek et al., 2014; Trobaja and Mann, 2019; Zhang et al., 2020) as all the resources required for the growth of diatom assemblage cells are restricted to specific biochemical roles (Wear et al., 2015; Barinova et al., 2019). The trophic status of a freshwater resource refers to the total weight of algal biomass. As a consequence, algal biomass has been identified as the most important effect that determines the composition of diatom species in freshwater ecosystems (Poulíčková et al., 2004; Klose et al., 2012; Barinova et al., 2019).

The concentration of nutrients like nitrate $\left(\mathrm{NO}_{3}{ }^{2-}\right)$ and phosphate $\left(\mathrm{PO}_{4}{ }^{2-}\right)$ are important variables, which aid the growth of diatoms (Kwon et al., 2013; Shinneman et al., 2016; Trobaja and Mann, 2019; Zhang et al., 2020). These are major factors which regulate the trophic status in aquatic ecosystems (Mensah et al., 2013; Trobaja and Mann, 2019). Phosphates are amongst the limited nutrients in the freshwater ecosystems and causes significant growth amongst diatoms (Winter and Duthie, 2000; Shinneman et al., 2016; Trobaja and Mann, 2019; Barinova et al., 2019; Zhang et al., 2020). The bio-accumulation in aquatic ecosystems has been reported to stem from animal wastes, fertilizers, sewage, detergents and other land use patterns (Walsh and Wepener, 2009). On the other hand, the bio-accumulation of nitrates in aquatic ecosystems originate from common forms of nitrogen available in the freshwater ecosystems. Reports (Giles, 2005) suggest that they are made available in the freshwater environment by the conversion of nitrogen gas $\left(\mathrm{N}_{2}\right)$ by algae or legumes into nitrate $\left(\mathrm{NO}_{3}{ }^{2-}\right)$ or by oxidation of ammonium gas $\left(\mathrm{NH}_{4}^{+}\right)$into nitrite $\left(\mathrm{NO}_{2}^{-}\right)$and to nitrate by bacteria. The depletion of phosphates and nitrates in freshwater ecosystems brings about perturbation in diatom communities which directly affect their productivity (Kwon et al., 2013; Shinneman et al., 2016; Trobaja and Mann, 2019; Barinova et al., 2019; Zhang et al., 2020). Diatoms are frequently used as biological indicators of trophic status and water quality conditions in rivers (Bellinger et al., 2006; Shinneman et al., 2016; Trobaja and Mann, 2019; Barinova et al., 2019; Zhang et al., 2020). Their application as bio-indicators in artificial or controlled environment has received little or no attention from researchers in recent years. The current study aims at monitoring the growth pattern of sampled benthic epilithic diatom assemblages in controlled optimized $\left(\mathrm{PO}_{4}{ }^{2-}\right.$ and $\left.\mathrm{NO}_{3}{ }^{2-}\right)$ amounts in algal growth media to ascertain if their diversity provides a better insight to their response to different nutrient concentrations. The study also aims at predicting the trophic status and water quality conditions of a freshwater resource like the Swartspruit River in the North West Province, South Africa by the controlled optimization of phosphate and nitrate $\left(\mathrm{PO}_{4}{ }^{2-}\right.$ and $\left.\mathrm{NO}_{3}{ }^{2-}\right)$ concentrations in benthic epilithic diatom assemblage cultures under laboratory conditions. To the best of our knowledge, little or no relevant information currently exist in the literature that reports the controlled optimization of $\mathrm{PO}_{4}{ }^{2-}$ and $\mathrm{NO}_{3}{ }^{2-}$ amounts in benthic epilithic diatom assemblage cultures in predicting the trophic status and water quality conditions of this surface freshwater reservoir. Our findings demonstrates that controlled optimization of $\mathrm{PO}_{4}{ }^{2-}$ and $\mathrm{NO}_{3}{ }^{2-}$ amounts in diatom assemblage cultures can be applied in predicting the trophic status and water quality conditions of the Swartpruit River, which is a very important inland freshwater resource available to inhabitants in the Greater Hartebeespoort Metropolitan Area in North West Province, South Africa. We are of the anticipation that the findings presented in this report can have a significant impact in 
integrating new knowledge with existing knowledge (if any) to gain a better insights into the state of water quality and safety around and downstream of the Swartspruit River, North West Province, South Africa.

\section{Materials and Methods}

\section{Study Site}

The Swartspruit River is located in Greater Hartbeespoort Metropolitan Area, North West Province, South Africa. The study sites include four station points, two located near the upstream water intake of the Jukskeispruit tributary JKSTT $\left(-25^{\circ} 74^{\prime} 9426^{\prime \prime} \mathrm{S}+27^{\circ} 90^{\prime} 4568^{\prime \prime} \mathrm{E}\right)$, the upstream water intake of the Rietvlei stream RTVLS $\left(-25^{\circ} 75^{\prime} 1059^{\prime \prime}+27^{\circ} 90^{\prime} 2755^{\prime \prime} \mathrm{E}\right)$, the upstream water intake of the Kaalspruitfontein stream KALTS $\left(25^{\circ} 74^{\prime} 9426^{\prime \prime S}+27^{\circ} 90^{\prime} 4568^{\prime \prime} \mathrm{E}\right)$ and the upstream water intake of the

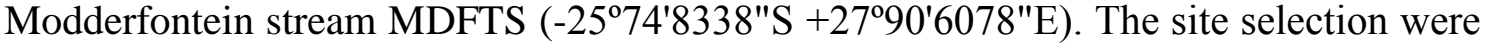
based on; (a) areas in the river that could easily be reached by either boat or by walking along the banks, (b) relative distance to fishing and animal conservation area, (c) relative distance to nearby water treatment facility, and (d) proximity to the Reinting waste water treatment plant. The sites were also chosen to be not less than ten meters $(10 \mathrm{~m})$ apart from one another and were located on areas with cobbles and boulders that are potential habitats for benthic epilithic diatoms (Desrosiers et al., 2013).

\section{Sample Collection of Diatom Materials}

Benthic epilithic diatom assemblage materials were collected in November 2014 - February 2015 from the river. Samples were collected not more than 10 meters from banks/littoral zone of the river. Water sample of about one litre was collected from each sample location in glass bowl. Five cobles/boulders within diameters $>64 \leq 256 \mathrm{~mm}$ were sampled for benthic epilithic diatom materials. Other debris attached to the stones were cautiously removed by agitating the stone in the water. With the aid of a brush, attached diatoms were brushed into the water sample placed on the bowl. Diatom material samples were then transferred to sample bottles and labelled accordingly with sample name, location and date.

\section{Preparation of WC Growth Media}

WC trace element solution was prepared by dissolving $0.436 \mathrm{~g} \mathrm{Na}_{2}$ EDTA and $0.315 \mathrm{~g}$ of $\mathrm{FeCl}_{3}$ in thirty milliliter $(30 \mathrm{~mL})$ of distilled water. Other micronutrients were added according established protocols. The solution was then transferred to a $100 \mathrm{~mL}$ volumetric flask and made up to volume with distilled water. For the preparation of each vitamin solutions, $2.4 \mathrm{~g}$ of 4-(2-hydroxyethyl)-1-piperazineethanesulfonic acid (HEPES) buffer was dissolved in $200 \mathrm{~mL}$ of deionized water. Subsequent amount (in grams) of vitamins; $\mathrm{B}_{12}$ (0.027), Thiamine (0.067) and Biotin (0.005) were added and allowed to completely dissolve (Geren et al., 2020).

\section{Cultivation of Diatom Assemblages in Control Optimized $\mathrm{PO}_{4}^{2-}$ and $\mathrm{NO}_{3}{ }^{2-}$ Growth Media}

For the preparation of one liter (1L) WC medium, approximately $900 \mathrm{~mL}$ of deionized water was measured in a measuring cylinder and transferred to a beaker. Then $1 \mathrm{~mL}$ each of the components $\left(\mathrm{NaNO}_{3}, \mathrm{CaCl}_{2}, \mathrm{MgSO}_{4}, \mathrm{NaHCO}_{3}, \mathrm{NaSiO}_{3}, \mathrm{~K}_{2} \mathrm{HPO}_{4}\right.$ and $\left.\mathrm{H}_{3} \mathrm{BO}_{3}\right)$ with 
the exception of vitamins which were added in an optimized order while stirring. The $\mathrm{pH}$ of the medium was adjusted to 7.8 accordingly. The volume of the solution was made up to one liter with deionized water. The vitamin solutions were added with a dropper and the mixture was allowed to mix properly. The medium was filter sterilized using a $0.45 \mu \mathrm{m}$ Millipore filter. Diatoms were then cultured in a volume of 20:180 mL of inoculum to medium. The diatom cultures were incubated for seven days at $20 \pm 2{ }^{\circ} \mathrm{C}$ under illumination. Cultures from the control experiment was then used as inoculum in the optimized $\mathrm{PO}_{4}{ }^{2-}$ and $\mathrm{NO}_{3}{ }^{2-}$ media. The cultures were in triplicates, in a volume of 20:180 $\mathrm{mL}$ of inoculum to medium. The diatom cultures were incubated for seven days at $20 \pm 2{ }^{\circ} \mathrm{C}$ under illumination before characterization. The amounts of phosphate and nitrate used in the P1 $-\mathrm{P} 12$ and $\mathrm{N} 1-\mathrm{N} 12$ treatments were $(0.003,0.005,0.01,0.015$, $0.025,0.05,0.1,0.15,0.2,0.25,0.3,0.4)$ and $(0.1,0.3,0.5,1.0,2.0,2.5,5,7,9,10,12$, 13) milligram per liter, respectively.

\section{Morphological Characterization of Sampled and Cultivated Diatoms}

The collected diatoms material samples were initially examined with the microscope to establish if the samples contained live diatom cells prior to cleaning. Aliquots of about ten millilitre $(10 \mathrm{~mL})$ of samples were used for microscopic characterization. The diatoms cells were cleaned using hot $\mathrm{HCl}$ and $\mathrm{KMnO}_{4}$ in order to completely remove organic matter present in sample and to dissolve any residual calcium carbonate (Trobajo et al., 2019). Cleaned diatom samples were mounted for microscopic characterization using Naphrax mounting medium (refractive index 1.69) obtained from Brunel microscope Ltd (Shinneman et al., 2016). Diatom valves mounted on slides were identified and counted using an oil immersion lens at 1000x magnification with a light microscope (Motic BA210) equipped with incident light. The field of view was used as the area defining the limits of the counts. All diatoms visible in the field of view were identified and counted before moving to the next field of view (Garvetto et al., 2018). Each individual specimen was counted as a single unit, without differentiation between a valve and frustules (Moorhouse et al., 2018). A minimum of 400 valves were counted and identified for each samples. The morphological identification of diatoms was done according to established protocols (Taylor et al., 2007; Zimmermann et al., 2015).

\section{Statistical Analysis}

Using XLSTAT software version 2016 (Addinsoft to Microsoft Excel 2016, New York, USA) principal component analysis (PCA) was performed to determine the relationship between optimized $\mathrm{PO}_{4}{ }^{2-}$ and $\mathrm{NO}_{3}{ }^{2-}$ amounts and diatom assemblage community compositions. Interpretation was done in angles between variables and between variables and PCA dimensions. Narrow angles in the biplots represented positively linked variables, right angles depicted variables that were unrelated to each other and obtuse angles represented negative relationship.

\section{Results}

\section{Taxonomic Profiles and Abundance of Diatom Assemblages in Control Growth Media}

Figure 1 denotes the taxonomic compositions and abundance of diatom assemblages in control culture. Benthic epilithic diatom specific counts and overall abundance of assemblages morphologically identified in the control culture are represented in the table. 
A total of 47 different species belonging to twenty 25 genera were identified in the control culture. The composition of individual species varied amongst taxa. Nitzchia linearis, Nitzchia perspicua, Rhopalodia operculata and Triblionella gracillis species had the minimum composition while Aulacoseira granulata var.augustissima had the maximum counts.

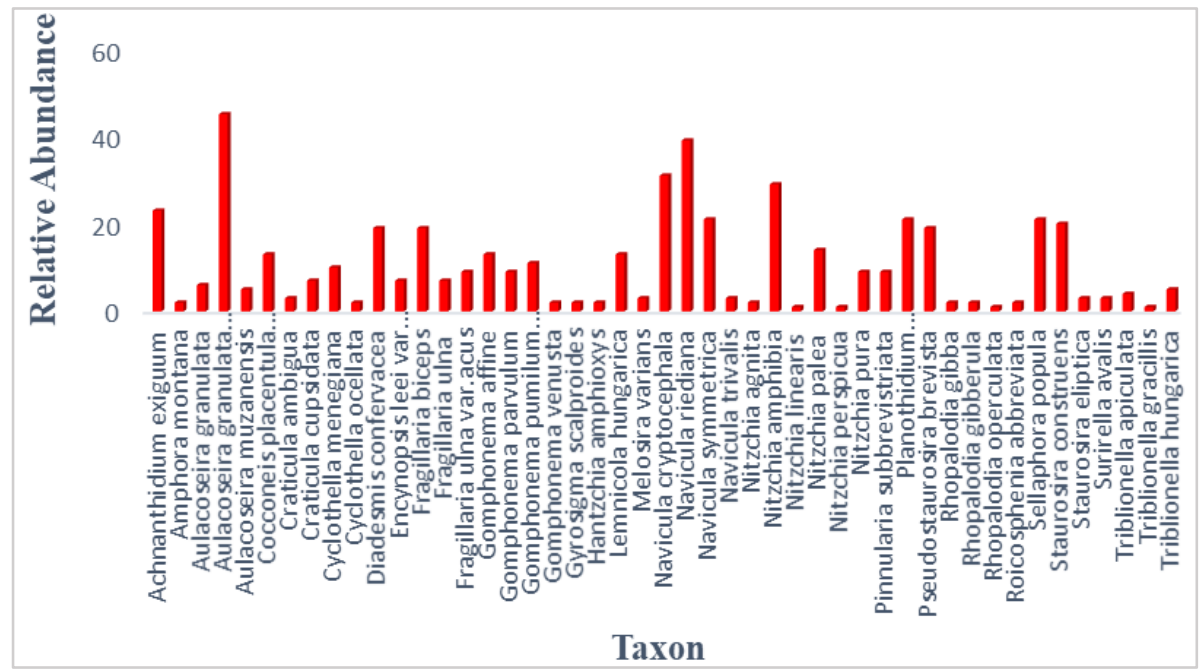

Figure 1. Taxonomic profiles and abundance of diatom assemblages in control growth media

\section{Taxonomic Profiles and Abundance of Diatom Assemblages in Optimized $\mathrm{PO}_{4}^{2-}$ Growth Media}

Figures 2 and 3 depicts the functional relative taxonomic profiles and abundance of diatom assemblages in optimized $\mathrm{PO}_{4}{ }^{2-}$ growth media and heat map of 25 genera in the optimized $\mathrm{PO}_{4}{ }^{2-}$ growth media, respectively. The 25 dominant genera in the optimized $\mathrm{PO}_{4}{ }^{2-}$ growth media were selected and compared with taxonomic profiles and abundance of benthic epilithic diatom assemblage cultures in the control growth media. The results obtained from P1 culture showed that the most prevalent species were Achantidiun exiguum, Aulacoseira granulata var. angustissima, Diademis confervacea, Navicula cryptocephala, Navicula rediana, Nitzchia amphibia, Nitzchia palea, Pseudostaurosira brevista and Sellaphora popula. The result also revealed that benthic epilithic diatoms assemblages that were depleting in the P1 culture include Cyclothela ocellata, Nitzchia agnita, Rhopalodia spp., Staurosira eliptica and Triblionella gracillis. The data obtained from P2 culture showed that the abundant diatom species were Achantidiun exiguum, Aulacoseira granulata var. angustissima, Fragillaria biceps, Navicula cryptocephala, Navicula rediana, Planothidiun frequentissimum, and Sellaphora popula. The data also indicated that benthic epilithic diatom species that were depleting includes Aulacoseira muzanensis, Nitzchia linearis, and Rhopalodia gibberula. P3 culture data revealed that Aulacoseira granulata var. angustissima, Navicula cryptocephala, Navicula rediana, Navicula symmetrica, Nitzchia pura, Pseudostaurosira brevista, Sellaphora popula and Staurosira construens were the dominant diatom species. Gyrosigma scalproides, Melosira varians, Navicula trivalis and Nitzchia agnita were depleting in this culture. Data obtained from P4 cultures showed that diatom species like Achantidiun exiguum, Aulacoseira granulata var. angustissima, Fragillaria biceps, Navicula cryptocephala, 
Navicula symmetrica, Nitzchia amphibia, Planothidiun frequentissimum and Sellaphora popula were dominant. Depleting benthic epilithic diatom species were Craticula ambigua, Cyclothella ocellata, Gyrosigma scalproides, Navicula trivalis, Rhopalodia gibberula, Rhopalodia operculata, Staurosira eliptica and triblionella gracillis. P5 culture showed Achantidiun exiguum, Aulacoseira granulata var. angustissima, Diademis confervacea, Fragillaria biceps, Navicula cryptocephala, Navicula rediana, Navicula symmetrica, Nitzchia amphibia, Nitzchia pura, Pseudostaurosira brevista and Staurosira construens as the dominant diatom species while species like Gomphonema venusta, Nitzchia agnita, Nitzchia perspicua and Staurosira eliptica were all depleting in this culture. In the P6 culture, Aulacoseira granulata, Aulacoseira granulata var. angustissima, Navicula cryptocephala, Navicula rediana, Navicula symmetrica, Nitzchia amphibia, Nitzchia pura, and Planothidiun frequentissimum diatom species showed abundant composition while Craticula ambigua, Cyclothella ocellata, Navicula trivalis, Nitzchia agnita and Rhopalodia operculata species displayed depleting trends. P7 cultures exhibited the abundance of diatom species like Achantidiun exiguum, Aulacoseira granulata var. angustissima, Fragillaria biceps, Fragillaria ulna var. acus, Navicula cryptocephala, Navicula symmetrica, Nitzchia amphibia, Nitzchia pura, Planothidiun frequentissimum and Sellaphora popula. Depleting diatom species observed in this culture include Gomphonema venusta, Gyrosigma scalproides, Rhopalodia gibba and Rhopalodia operculata. P8 species composition showed that Achantidiun exiguum, Aulacoseira granulata var. angustissima, Navicula cryptocephala, Planothidiun frequentissimum and Sellaphora popula species were dominant. The data also showed that Hantzchia amphioxys, Lemnicola hungarica, Navicula trivalis, Nitzchia agnita, Nitzchia linearis, Rhopalodia gibba and Rhopalodia gibberula were depleting. Results obtained from P9 culture showed that diatom species which dominated were Achnantidiun exiguum, Aulacoseira granulata, Aulacoseira granulata var. angustissima, Navicula cryptocephala, Nitzchia pura, Planothidiun frequentissimum and Sellaphora popula. Accordingly, species composition revealed that Gomphonema venusta, Nitzchia agnita, Nitzchia linearis, Rhopalodia operculata and Staurosira eliptica were depleting. Diatom species composition analysis clearly showed that in P10 culture, Achantidiun exiguum, Aulacoseira granulata var. angustissima, Diademis confervacea, Navicula cryptocephala and Planothidiun frequentissimum were the dominant diatom species, while Craticula ambigua, Gomphonema pumilum var. rigidum, Gomphonema venusta, Hantzchia amphioxys, Navicula trivalis, Nitzchia agnita, Rhopalodia gibba and Rhopalodia gibberula diatom species were depleting. Diatom species composition analysis in P11 culture showed that Achnantidiun exiguum, Aulacoseira granulata, Aulacoseira granulata var. angustissima, Navicula cryptocephala, Navicula reidiana, Planothidiun frequentissimum and Sellaphora popula were dominant while Gomphonema pumilum var. rigidum, Gomphonema venusta, Lemnicola hungarica, Nitzchia agnita, Nitzchia perspicua, Pinnularia subbrevistriata, Pseudostaurosira brevista and Rhopalodia spp all displayed depleting trends. P12 cultures clearly shows that diatom species like Achnantidiun exiguum, Aulacoseira granulata var. angustissima, Gomphonema parvulu, Navicula cryptocephala, Planothidium frequentissimum and Sellaphora popula were dominant while diatom assemblages like Cocconeis placentula var euglipta, Craticula ambigua, Gyrosigma scalproides, Lemnicola hungarica, Rhopalodia gibba, Rhopalodia operculata, Staurosira eliptica and Triblionella hungarica species showed depleting trends. 


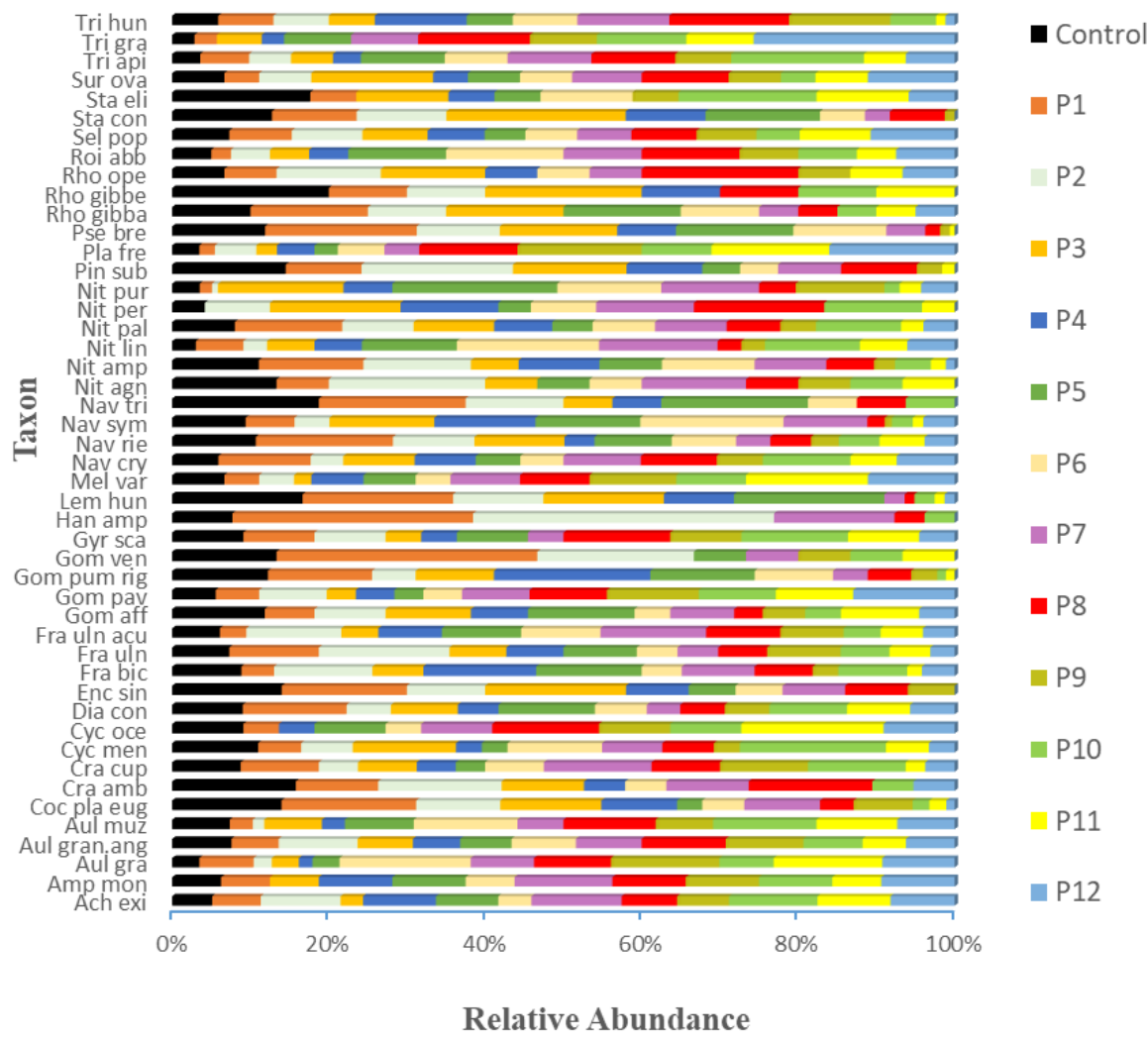

Figure 2. Functional relative taxonomic profiles and abundance of diatom assemblages in optimized $\mathrm{PO}_{4}^{2-}$ growth media

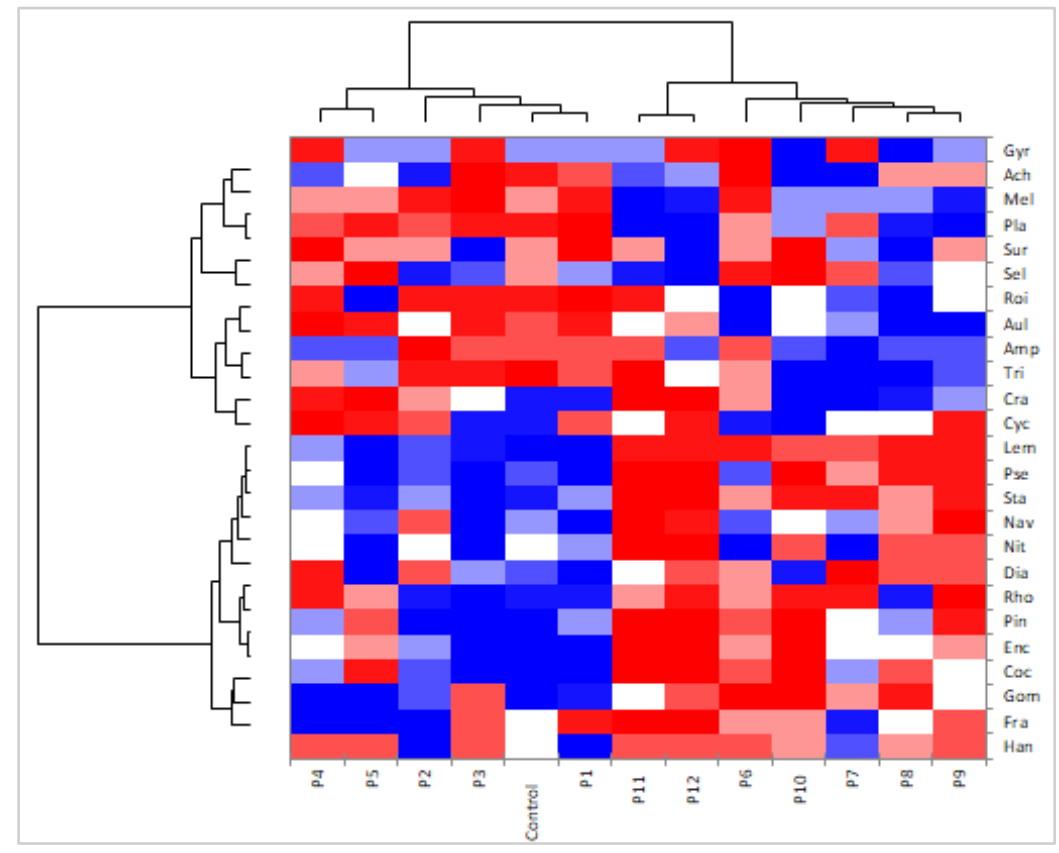

Figure 3. Heat map depicting 25 genera in the optimized $\mathrm{PO}_{4}^{2-}$ growth media. The 25 dominant genera in the optimized $\mathrm{PO}_{4}^{2-}$ growth media were selected and compared with taxonomic profiles and abundance of benthic epilithic diatom assemblage cultures in the control growth media 
Figure 4 is a PCA ordination biplot depicting the relationship between the taxonomic diversity profiles and abundance of the benthic epilithic diatom assemblages and optimized $\mathrm{PO}_{4}{ }^{2-}$ concentration in the growth media. The biplot portrays $45.62 \%$ of variations in the data with the $\mathrm{F} 1$ axis representing $31.56 \%$ and the $\mathrm{F} 2$ axis denoting $14.06 \%$. The data illustrated that there was a definite separation among cultures on the F1 axis. The separation showed P1 - P6 on the positive margin and P7 - P12 on the negative. The P1 - P6 had $\mathrm{PO}_{4}{ }^{2-}$ amounts which ranged from $0.003-0.05 \mathrm{mg} / \mathrm{L}$, indicating that higher $\mathrm{PO}_{4}{ }^{2-}$ amounts were mainly dominated by the presence of Gomphonema pavulum, Planothidium frequentissimum, Melosira varians, Sellaphora popula, Aulacoseira spp., Cyclothella spp., Triblionella spp. and Roicosphenia species. Lower phosphate concentrations (P1 - P5) favoured the growth of Fragillaria, Nitzchia, Encynopsis, Ropalodia, Navicula and Gomphonema species. The P1 - P5 cultures representing a non-impacted water quality conditions encouraged a wide diversity of benthic epilithic diatom assemblages. Similarly, P7 - P12 cultures representing an impacted water quality conditions / higher trophic status indicates that only taxa with preference for the optimized $\mathrm{PO}_{4}{ }^{2-}$ amounts were present.

Biplot (axes F1 and F2: $45.62 \%$ )

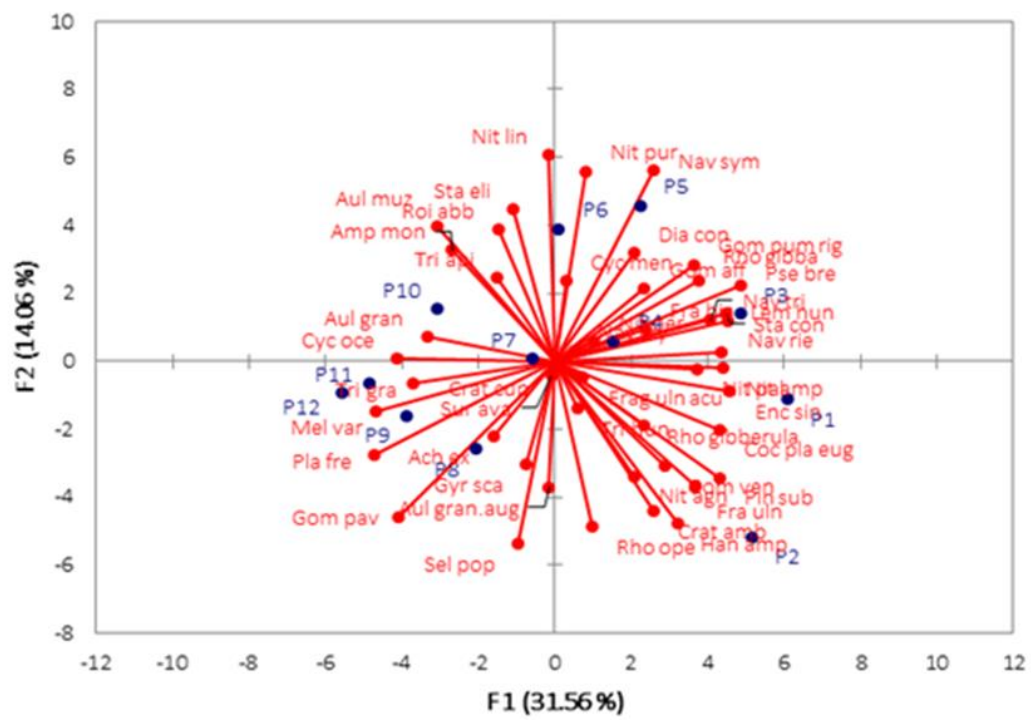

Figure 4. PCA biplot illustrating the corelation between taxonomic compositions and abundance of benthic epilithic diatom assemblages in optimized $\mathrm{PO}_{4}^{2-}$ growth media

\section{Taxonomic Profiles and Abundance of Diatom Assemblages in Optimized $\mathrm{NO}_{3}{ }^{2-}$ Growth Media}

Figures 5 and 6 depicts the functional relative taxonomic profiles and abundance of diatom assemblages in optimized $\mathrm{NO}_{3}{ }^{2-}$ growth media and heat map depicting 25 genera in the optimized $\mathrm{NO}_{3}{ }^{2-}$ growth media. The 25 dominant genera in the optimized $\mathrm{NO}_{3}{ }^{2-}$ growth media were selected and compared with taxonomic profiles and abundance of benthic epilithic diatom assemblage cultures in the control growth media. The data obtained from N1 culture showed that the most prevalent species were Achnantidium exiguum, Aulacoseira granulata, Cocconeis placentula var. Euglypta, Fragillaria ulna var. acus, Navicula crytocephala, Navicula reidiana, NItzchia amphibia, Nitzchia palea, 
Pseudostaurosira brevista, Sellaphora popula and Staurosira construens. The only diatom species observed exhibiting a depleting trend was Rhopalodia gibba. The data from N2 culture revealed that the abundant diatom species were Achnanthidium exiguum, Aulacoseira granulata, Navicula cryptocephala and Nitzchia palea. Depleting species included Gomphonema pumilum var. rigidum, Navicula trivalis and Staurosira eliptica species. N3 culture showed that Achnanthidium exiguum, Aulacoseira granulata, Fragillaria ulna var.acus, Navicula reidiana and Sellaphora popula dominating. The only diatom species observed depleting was Gyrosigma scalproides. Results obtained from N4 cultures showed that diatom species like Achnanthidium exiguum, Diademis confervacea, Fragillaria ulna var. acus, Gomphonema parvulum, Navicula cryptocephala, Navicula reidiana and Nitzchia palea were dominant. Benthic epilithic diatom species observed depleting were Craticula ambigua, Navicula trivalis, Nitzchia linearis, Nitzchia perspicua, Pinnularia subbrevistriata, Rhopalodia operculata, Staurosira eliptica and triblionella hungarica. N5 culture showed that Achnanthidium exiguum, Aulacoseira granulata, Aulacoseira granulata var. angustissimum, Fragillaria ulna var. acus, Gomphonema parvulum, Navicula cryptocephala, Navicula reidiana and Nitzchia amphibia, Planothidium frequentissimum, Pseudostaurosira brevista and Sellaphora popula were dominant. Diatom species depleting in this culture were Aulacoseira muzzanensis, Craticula ambigua, Cyclothella ocellata, Gyrosigma scalproides, Melosia varians, Navicula trivalis, Rhopalodia operculata and Surrirella avalis. In the N6 culture, Achnanthidium exiguum, Aulacoseira granulata, Aulacoseira granulata var. angustissimum, Diademis confervacea, Fragillaria ulna var. acus, Navicula cryptocephala, Navicula reidiana, Navicula symmetrica, Nitzchia amphibia, Nitzchia palea, Planothidium frequentissimum and Pseudostaurosira brevista. Diatom species like Gyrosigma scalproides, Hantzchia amphioxys, Navicula trivalis, Rhopalodia gibberula, Rhopalodia operculata and Triblionella hungarica displayed depleting trends. N7 cultures exhibited the abundance of diatom species like Achnanthidium exiguum, Aulacoseira granulata, Navicula symmetrica and Pseudostaurosira brevista. Diatom species which were depleting are Encynopsis leei var. sinnensis, Gomphonema venusta, Nitzchia linearis, Nitzchia perspicua, Rhopalodia gibba, Staurosira construens and Triblionella gracillis. N8 species composition showed that Achnanthidium exiguum, Aulacoseira granulata, Aulacoseira granulata var. angustissimum, Fragillaria ulna, Gomphonema parvulum, Navicula reidiana, Navicula symmetrica, Nitzchia amphibia, and Planothidium frequentissimum were dominant. Depleting species were Nitzchia linearis, Nitzchia perspicua, and Staurosira eliptica. The N9 culture showed that diatom species which dominated were Achnanthidium exiguum, Aulacoseira granulata, Aulacoseira granulata var. angustissimum, Fragillaria ulna var. acus, Navicula cryptocephala Navicula reidiana, Navicula symmetrica, Planothidium frequentissimum and Pseudostaurosira brevista. The depleting species were Craticula ambigua, Gomphonema venusta, Gyrosigma scalproides, Navicula trivalis, Nitzchia agnita, Rhopalodia operculata, Triblionella gracillis and Triblionella hungarica. Diatom species composition analysis clearly showed that in N10 culture, Achnanthidium exiguum, Aulacoseira granulata, Aulacoseira granulata var. angustissimum, Fragillaria ulna var. acus, Gomphonema parvulum, Navicula cryptocephala, Navicula reidiana, Nitzchia amphibia, Planothidium frequentissimum, Pseudostaurosira brevista and Sellaphora popula were dominant. Gomphonema pumilum var. rigidum was the only depleting diatom species. Diatom species composition analysis in N11 culture showed that Achnanthidium exiguum, Aulacoseira granulata, Aulacoseira granulata var. 
angustissimum, Diademis confervacea, Gomphonema parvulum, Navicula cryptocephala, Navicula reidiana, Nitzchia amphibia, Planothidium frequentissimum and Pseudostaurosira brevista were dominant. The diatom species observed depleting were craticula cupsidata, Gyrosigma scalproides, Nitzchia agnita, Nitzchia perspicua, NItzchia pura, Rhopalodia gibberula, Rhopalodia operculata, Staurosira eliptica, Triblionella gracillis and Triblionella hungarica. N12 cultures clearly shows that diatom species like Achnanthidium exiguum, Aulacoseira granulata, Aulacoseira granulata var. angustissimum, Gomphonema parvulum, Navicula cryptocephala, Navicula reidiana, Nitzchia amphibia, and Planothidium frequentissimum. Diatom species observed depleting were Encynopsis leei var. sinnensis, Gyrosigma scalproides, Lemnicola hungarica, Nitzchia agnita, Nitzchia linearis, Pinnularia subbrevistriata, Rhopalodia, Staurosira and Triblionella spp.

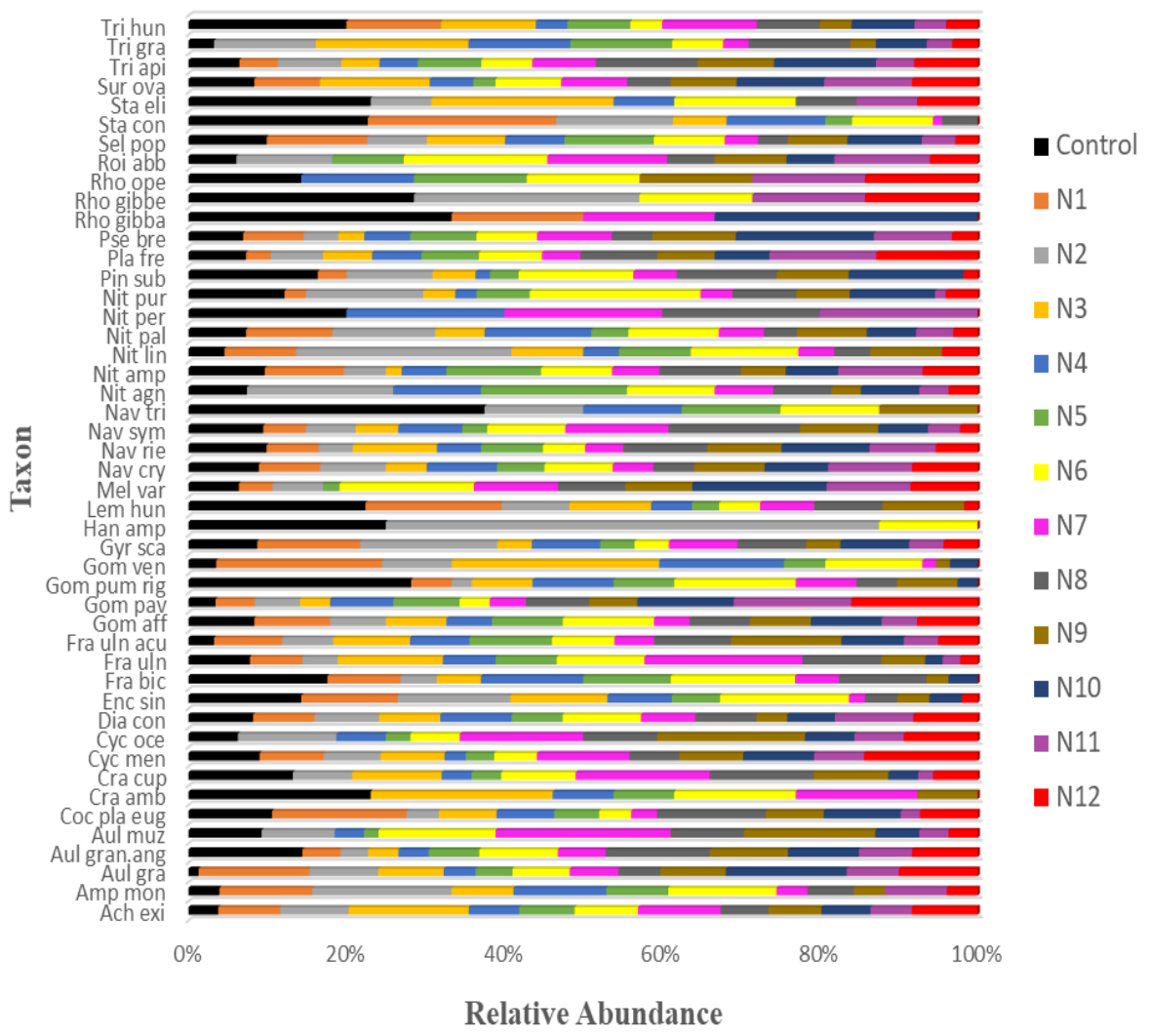

Figure 5. Taxonomic profiles and abundance of diatom assemblages in optimized $\mathrm{NO}_{3}{ }^{2-}$ growth media

Figure 7 is a PCA biplot denoting the relationship between the taxonomic diversity profiles and abundance of benthic epilithic diatom assemblages and optimized $\mathrm{NO}_{3}{ }^{2-}$ concentrations in the growth media. The biplot describes $37.93 \%$ of variations in the data with the F1 axis describing $21.72 \%$ and the F2 axis denoting $16.21 \%$ of variations. The data demostrated that N4 - N6 cultures were more correlated with Encynopsis, Gyrosigma, Nitzchia, Hantzchia, Navicula, Diademis, Amphora and Rhopalodia diatom species. N7-N12 cultures favoured the growth of Roicosphenia, Navicula, Gomphonema, Aulacoseira, Cyclothela, Rhoalodia, Pseudostaurosira, Surrirella and Triblionella species. 


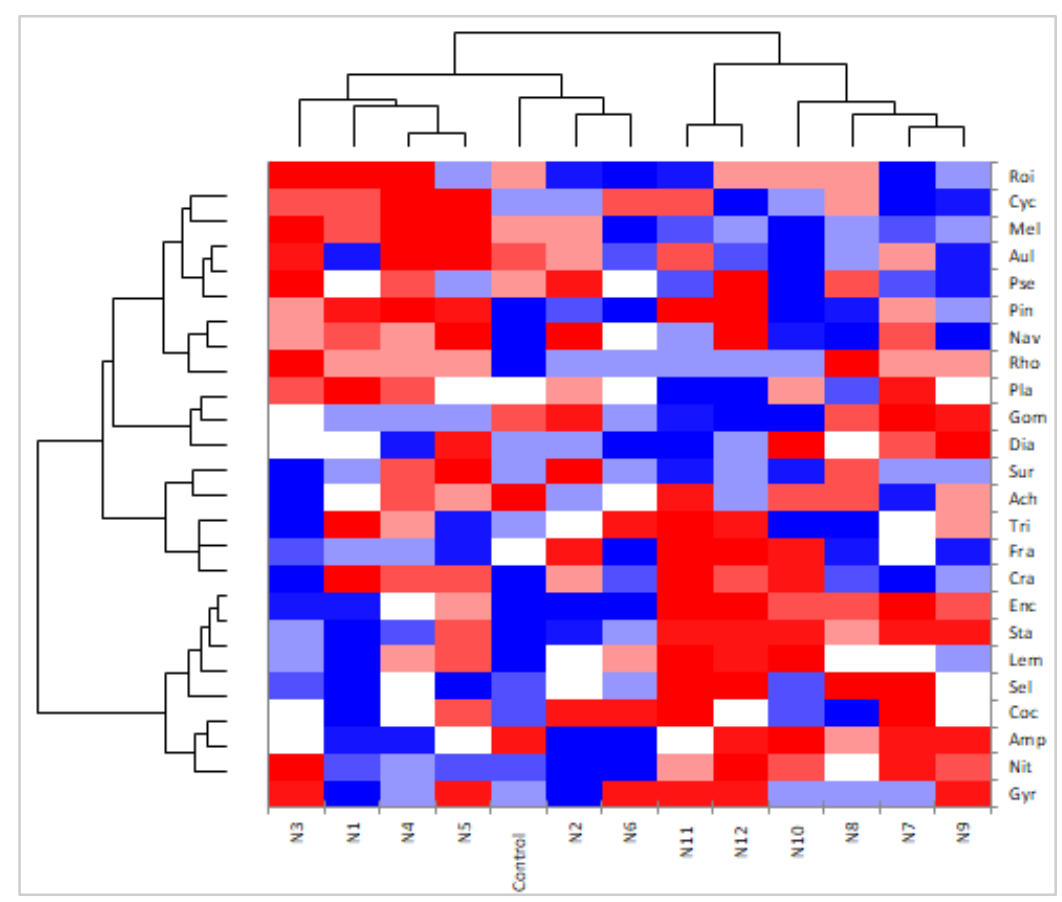

Figure 6. Heat map depicting 25 genera in the optimized $\mathrm{NO}_{3}{ }^{2-}$ growth media. The 25 dominant genera in the optimized $\mathrm{PO}_{4}^{2-}$ growth media were selected and compared with taxonomic profiles and abundance of benthic epilithic diatom assemblage cultures in the control growth media

Biplot (axes F1 andF2: $37.93 \%$ )

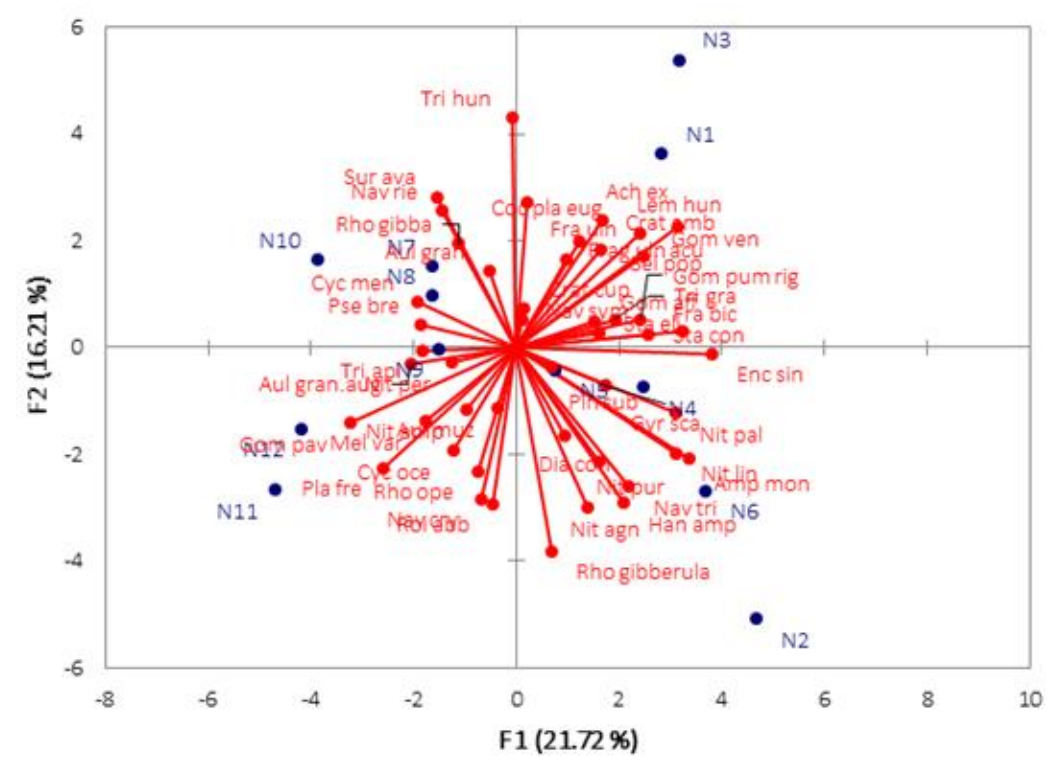

Figure 7. PCA biplot depicting the corelation between taxonomic diversity profile and abundance of benthic epilithic diatom assemblages in optimized $\mathrm{NO}_{3}{ }^{2-}$ concentration growth media 


\section{Discussion}

The results clearly indicated that the prevalence of benthic epilithic diatom assemblages could be related to phosphate and nitrate trophic status in a controlled environment. The amount of $\mathrm{PO}_{4}{ }^{2-}$ and $\mathrm{NO}_{3}{ }^{2-}$ in the control WC media was $0.0087 \mathrm{mg} / \mathrm{L}$ and $0.0851 \mathrm{mg} / \mathrm{L}$, respectively. These concentrations are within the mesotrophic and oligitrophic condition which is consistent with a non-polluted (good water quality) trophic status (Tables 1 and 2).

Table 1. Actual nutrient concentrations that determine the trophic level of river systems

\begin{tabular}{c|c|c|c|c|c|c}
\hline Physicochemical & \multicolumn{7}{|c}{ Trophic level } \\
variables & V. low (1) & Low (2) & Moderate (3) & High (4) & V. high (5) & Ex. High (6) \\
\cline { 2 - 7 } Phosphate $(\mu \mathrm{g} / \mathrm{L})$ & $<20$ & $20-60$ & $60-100$ & $100-200$ & $200-1000$ & $>1000$ \\
Nitrate $(\mathrm{mg} / \mathrm{L})$ & $<5$ & $5-10$ & $10-20$ & $20-30$ & $30-40$ & $>40$ \\
$\begin{array}{c}\text { Dissolved oxygen } \\
(\% \text { saturation) }\end{array}$ & 80 & 70 & 60 & 50 & 20 & $<20$ \\
\hline
\end{tabular}

Table 2. Trophic levels of inland freshwater ecosystem

\begin{tabular}{c|c|c}
\hline \multirow{2}{*}{ Trophic category } & \multicolumn{2}{|c}{ Variables } \\
\cline { 2 - 3 } & Nitrate $\left(\mathrm{mgL}^{-1}\right)$ & Phosphate $\left(\mu \mathrm{gL}^{-1}\right)$ \\
\hline Oligotrophic & $<0.5$ & $>5.0$ \\
Mesotrophic & $0.5-2.5$ & $5-25$ \\
Eutrophic & 2.510 & $25-250$ \\
Hypertrophic & $>10$ & $>250$ \\
\hline
\end{tabular}

A total of 47 different species belonging to twenty 25 genera were identified in the control culture. The composition of individual species varied amongst taxa (Figure 1). Aulacoseira granulata var.augustissima had the maximum counts suggesting that the species can florish in oligo- mesotrophic conditions corroborating earlier reports by Taylor et al. (2007) who reported that Aulacoseira granulata var.augustissima can be found in eutrophic rivers. Similar conditions existed in the river when environmental samples were collected suggesting that this species can florish in both polluted and non polluted environments. Comparatively Nitzchia linearis, Nitzchia perspicua, Rhopalodia operculata and Triblionella gracillis species were depleting in this culture medium indicating that these species do not florish very well under oligo-mesotrophic conditions. Such findings corroborates earlier studies by Bere et al. (2013), Shinneman et al. (2016), Trobaja and Mann (2019), Barinova et al. (2019) and Zhang et al. (2020) which reported that Nitzchia linearis is tolerant of polluted condition. P1 and P2 cultures $(0.003$ and 0.005 $\mathrm{mg} / \mathrm{L} \mathrm{PO}_{4}{ }^{2-}$ ) represents oligotrophic water condition (Tables 1 and 2 ). The data obtained from these cultures showed that the most prevalent species were Achantidiun exiguum, Aulacoseira granulata var. angustissima, Diademis confervacea, Fragillaria biceps, Navicula cryptocephala, Navicula rediana, Nitzchia amphibia, Nitzchia palea, Planothidiun frequentissimum Pseudostaurosira brevista and Sellaphora popula. These species could prevail and dominate in non-polluted environments corroborating reports (Taylor et al., 2007; Shinneman et al., 2016; Trobaja and Mann, 2019; Barinova et al., 2019; Zhang et al., 2020) who have reported that these species are prevalent in different 
trophic water levels including eutrophic and extremely polluted waters. The depletion of benthic epilithic diatom species (Figures 2 and 3) like Aulacoseira muzanensis, Cyclothela ocellata, Nitzchia agnita, Nitzchia linearis, Rhopalodia spp., Staurosira eliptica and Triblionella gracillis in the $\mathrm{P} 1$ and $\mathrm{P} 2$ cultures plausibly indicated that these species do not flourish in oligotrophic conditions. Literature reports (Shinneman et al., 2016; Moorhouse et al., 2018; Trobaja and Mann, 2019; Barinova et al., 2019; Zhang et al., 2020) describing the prevalence of Aulacoseira muzanensis, Cyclothela ocellata and Nitzchia linearis in meso-eutrophic waters supports this assertion. P3, P4 and P5 cultures with $0.01,0.015$ and $0.025 \mathrm{mg} / \mathrm{L} \mathrm{PO}_{4}{ }^{2-}$ respectively represents a mesotrophic water quality condition (Tables 1 and 2). Species abundance analysis of these cultures (Figures 2 and 3) showed Achnantidiun exiguum, Aulacoseira granulata var. angustissima, Diademis confervacea, Fragillaria biceps, Navicula cryptocephala, Navicula rediana, Navicula symmetrica, Nitzchia amphibia, Nitzchia pura, Planothidiun frequentissimum Pseudostaurosira brevista Sellaphora popula and Staurosira construens were the dominant diatom assemblages. These species could also prevail and dominate in non-polluted environments also corroborating reports (Harding et al., 2005) who has reported that these species are prevalent in diverse freshwaters resources including eutrophic and extremely polluted surface waters. Our assumption is that the depletion of diatoms species (Figures 2 and 3) like Craticula ambigua, Cyclothella ocellata, Gomphonema venusta, Gyrosigma scalproides, Melosira varians, Navicula trivalis, Nitzchia agnita, Nitzchia perspicua, Rhopalodia gibberula, Rhopalodia operculata, Staurosira eliptica and Triblionella gracillis in the P3, P4 and P5 cultures may be an indication that these species do not flourish in mesotrophic conditions. This is due to the fact that published reports (Shinneman et al., 2016; Moorhouse et al., 2018; Trobaja and Mann, 2019; Barinova et al., 2019; Zhang et al., 2020) describing the prevalence of Craticula ambigua, Cyclothella ocellata, Gomphonema venusta, Gyrosigma scalproides, Melosira varians, Navicula trivalis, Nitzchia agnita, Nitzchia perspicua, Rhopalodia gibberula, Rhopalodia operculata, Staurosira eliptica and Triblionella gracillis in mesoeutrophic waters supports this proposition. P6, P7, P8, P9 and P10 cultures having 0.05, $0.1,0.15,0.2$ and $0.25 \mathrm{mg} / \mathrm{L} \mathrm{PO}_{4}{ }^{2-}$ respectively signifies a eutrophic water quality condition (Tables 1 and 2). Again species abundance analysis (Figures 2 and 3) of these cultures indicated that Achantidiun exiguum, Aulacoseira granulata var. angustissima, Aulacoseira granulata, Diademis confervacea, Fragillaria biceps, Fragillaria ulna var. acus, Navicula cryptocephala Navicula rediana, Navicula symmetrica, Nitzchia amphibia, Nitzchia pura, Planothidiun frequentissimum Sellaphora popula were the dominant diatom species. The data also showed diatom species like Craticula ambigua, Cyclothella ocellata, Gomphonema pumilum var. rigidum, Gomphonema venusta, Gyrosigma scalproides, Hantzchia amphioxys, Lemnicola hungarica, Navicula trivalis, Nitzchia agnita Nitzchia linearis, Rhopalodia gibba Rhopalodia gibberula Rhopalodia operculata and Staurosira eliptica were depleting under eutrophic conditions. The depletion of these species under similar water trophic status corroborates previous reports (Lacerda et al., 2004; Della Bella et al., 2007) who have hypothesized the depletion of some of the species in eutrophic waters. P11 and P12 cultures $\left(0.3,0.4 \mathrm{mg} / \mathrm{L} \mathrm{PO}_{4}{ }^{2-}\right)$ presented a hyper-eutrophic water conditions (Tables 1 and 2). Diatom species composition analysis in these cultures revealed that Achnantidiun exiguum, Aulacoseira granulata var. angustissima, Aulacoseira granulata, Gomphonema parvulu, Navicula cryptocephala, Navicula reidiana, Planothidium frequentissimum sellaphora popula were the dominant species. The revelation reasonably indicates that these species are 
tolerant of hyper-eutrophic to extremely polluted conditions (Leelahakriengkrai and Peerapornpisal, 2010). The data also revealed that species like Cocconeis placentula var euglipta, Craticula ambigua, Gomphonema pumilum var. rigidum, Gomphonema venusta, Gyrosigma Scalproides, Lemnicola hungarica, Nitzchia agnita, Nitzchia perspicua, Pinnularia subbrevistriata, Pseudostaurosira brevista, Rhopalodia spp. Staurosira eliptica and Triblionella hungarica all displayed depleting trends under hypereutrophic conditions corroborating previous reports (Leland and Porter, 2000; Leira and Sabater, 2005; Salomoni et al., 2006). However, the depletion of Craticula ambigua and Triblionella hungarica under hyper-eutrophic conditions is in disagreement with Taylor et al. (2007) who has reported that these species are tolerant of critically polluted waters. An analysis to evaluate the correlation between diatom diversity and optimized $\mathrm{PO}_{4}{ }^{2-}$ amounts in the growth media was done using principal component analysis (Figure 4). The results portrays $45.62 \%$ of variations in the data. The F1 axis describes $31.56 \%$ and the F2 axis describes $14.06 \%$ plausibly suggesting that the the optimization of $\mathrm{PO}_{4}{ }^{2-}$ concentrations encouraged corresponding fluctuations in the diversity and abundance of diatom assemblages. P1 - P6 cultures (oligo-mesotrophic conditions) displayed separation on the F1 axis, and favoured enormous diversity of diatoms which could be attributed to non-polluted water trophic status. The oligo-mesotrophic water conditions were mainly dominated by Fragillaria, Nitzchia, Encynopsis, Ropalodia, Navicula and Gomphonema species. The prevalence of these species in moderate $\mathrm{PO}_{4}{ }^{2-}$ amounts have been reported in streams and rivers (Bellinger et al., 2006; Moorhouse et al., 2018). According to Bellinger et al. (2006), diatoms react profusely to even minor concentrations of phosphate. P7 - P12 cultures with higher phosphate concentrations (eutrophic-hypereutrophic conditions) had lower diversity of diatoms. The eutrophic - hyper-eutrophic water quality conditions were mainly dominated by presence of Gomphonema pavulum, Planothidium frequentissimum, Melosira varians, Sellaphora popula, Aulacoseira spp., Cyclothella spp., Triblionella spp. and Roicosphenia species suggesting that only taxa with preference to optimized phosphate concentrations were present.

Similarly, $\mathrm{N} 1$ and $\mathrm{N} 2$ cultures $\left(0.1\right.$ and $\left.0.3 \mathrm{mg} / \mathrm{L} \mathrm{NO}_{3}{ }^{2-}\right)$ represents the oligotrophic water condition (Tables 1 and 2). The data obtained from these cultures revealed that the most prevalent species were Achnanthidium exiguum, Aulacoseira granulata, Cocconeis placentula var. euglypta, Fragillaria ulna var. acus, Navicula cryptocephala, Navicula reidiana, Nitzchia amphibia, Nitzchia palea, Pseudostaurosira brevista, Sellaphora popula and Staurosira construens. Navicula cryptocephala, Pseudostaurosira brevista and Staurosira construens species could prevail and dominate in oligotrophic environments corroborating reports (Taylor et al., 2007). The depletion of benthic epilithic diatom species (Figures 5 and 6) like Gomphonema pumilum var. rigidum, Navicula trivalis, Rhopalodia gibba and Staurosira eliptica in N1 and N2 cultures practically indicated that these species do not flourish in oligotrophic conditions (Trobajo et al., 2019). N3, N4, N5 and N6 cultres $\left(0.5,1.0,2.0,2.5 \mathrm{mg} / \mathrm{L} \mathrm{NO}_{3}{ }^{2-}\right)$ represents a mesotrophic water condition (Tables 1 and 2). Species abundance analysis of these cultures (Figures 5 and 6 ) showed that Achnanthidium exiguum, Aulacoseira granulata var. angustissimum, Aulacoseira granulata, Diademis confervacea, Fragillaria ulna var. acus, Gomphonema parvulum, Navicula cryptocephala, Navicula reidiana, Navicula symmetrica, Nitzchia amphibia, Nitzchia palea, Planothidium frequentissimum, Pseudostaurosira brevista and Sellaphora popula were dominant. The results showed that Achnanthidium exiguum, Diademis confervacea, Fragillaria ulna var. acus, Gomphonema parvulum, Navicula cryptocephala, Planothidium frequentissimum, 
Pseudostaurosira brevista and Sellaphora popula could prevail and dominate in mesotrophic environments corroborating reports (Taylor et al., 2007; Shinneman et al., 2016; Trobaja and Mann, 2019; Barinova et al., 2019; Zhang et al., 2020). However, the dominant presence of species like Aulacoseira granulata var. angustissimum, Aulacoseira granulata, Navicula reidiana, Navicula symmetrica, Nitzchia amphibia and Nitzchia palea in mesotrophic water conditions is in disagreement with the findings of Bere et al. (2013) who reported that these diatom species persist mostly in eutrophic and extremely polluted environments. In constrast, the depletion of diatoms species (Figures 5 and 6) like Aulacoseira muzzanensis, Craticula ambigua, Cyclothella ocellata, Gyrosigma scalproides, Hantzchia amphioxys, Melosira varians, Navicula trivalis, Nitzchia linearis, Nitzchia perspicua, Pinnularia subbrevistriata, Rhopalodia gibberula, Rhopalodia operculata, Staurosira eliptica, Surrirella avalis and Triblionella hungarica in these cultures presumably implies that these species do not flourish in mesotrophic conditions (Chia et al., 2011; Trobajo et al., 2019). N7, N8, N9 and N10 (5.0, 7.0, 9.0, $10 \mathrm{mg} / \mathrm{L} \mathrm{NO}_{3}{ }^{2-}$ ) represents a eutrophic water condition (Tables 1 and 2). Species abundance analysis of these cultures showed that diatom species like Achnanthidium exiguum, Aulacoseira granulata var. angustissimum, Aulacoseira granulata, Fragillaria ulna, Fragillaria ulna var. acus, Gomphonema parvulum, Navicula cryptocephala, Navicula reidiana, Navicula symmetrica, Nitzchia amphibia, Planothidium frequentissimum, Pseudostaurosira brevista and Sellaphora popula were dominant in these cultures. The data credibly suggest that these species could prevail and dominate in eutrophic freshwater environments. The depletion of diatoms species like (Figures 5 and 6) Craticula ambigua, Encynopsis leei var. sinnensis, Gomphonema pumilum var. rigidum, Gomphonema venusta, Gyrosigma scalproides, Navicula trivalis, Nitzchia agnita, Nitzchia linearis, Nitzchia perspicua, Rhopalodia gibba, Rhopalodia operculata, Staurosira construens, Staurosira eliptica, Triblionella gracillis, Triblionella hungarica in constrast may again insinuate their intolerance to eutrophic freshwater conditions. Equally, the depletion of Encynopsis leei var. sinnensis, Gomphonema venusta and Staurosira construens under eutrophic water conditions surprisingly is in disagreement with Harding et al. (2005) and Barinova et al. (2019) who are of the opinion that these species can flourish and dominate in eutrophic freshwater conditions. N11, N12 and $\mathrm{N} 13\left(11,12,13 \mathrm{mg} / \mathrm{L} \mathrm{NO}_{3}{ }^{2-}\right)$ denote a hyper-eutrophic water condition (Tables 1 and 2). Again species abundance analysis of these cultures (Figures 5 and 6 ) showed that diatom species like Achnanthidium exiguum, Aulacoseira granulata var. angustissimum, Aulacoseira granulata, Diademis confervacea, Gomphonema parvulum, Navicula cryptocephala, Navicula reidiana, Nitzchia amphibia, Planothidium frequentissimum and Pseudostaurosira brevista were dominant in these cultures. The data undoubtedly implied that these species could prevail and dominate in hyper-eutrophic environments. It is worth mentioning that diatom species like Aulacoseira granulata var. angustissimum, Aulacoseira granulata, Navicula reidiana and Pseudostaurosira brevista have been reported to flourish under hyper-eutrophic environments (Della Bella et al., 2007). The depletion of benthic epilithic diatom assemblages (Figures 5 and 6) Craticula cupsidata, Encynopsis leei var. sinnensis, Gyrosigma scalproides, Lemnicola hungarica, Nitzchia agnita, Nitzchia linearis, Nitzchia perspicua, Nitzchia pura, Pinnularia subbrevistriata, Rhopalodia, Staurosira and Triblionella spp suggest that these species could flourish well in waters of good quality (Della Bella et al., 2007). Correspondingly, an analysis to evaluate the correlation between diatom diversity and optimized $\mathrm{NO}_{3}{ }^{2-}$ amounts in the growth media was done using principal component analysis (Figure 7). The data 
illustrated $37.93 \%$ of variations in the data. The $\mathrm{F} 1$ axis describes $21.72 \%$ and the $\mathrm{F} 2$ axis describes $16.21 \%$ of variations, revealing that the optimization of $\mathrm{NO}_{3}{ }^{2-}$ amounts within mesotrophic to hyper-eutrophic conditions displayed correlation with specific diatom species. The PCA ordination biplot illustrated that N1 - N3 cultures (oligotrophic slightly mesotrophic conditions) did not have any correlation with the distribution of diatom species. N4 - N6 cultures (mesotrophic condition) were more correlated with Amphora, Diademis, Encynopsis, Gyrosigma, Hantzchia, Navicula, Nitzchia and Rhopalodia spp. According to Taylor et al. (2007), Encynopsis leei var. sinensis species can be found in oligo-mesotrophic water condition. The PCA ordination biplot also showed that N7-N12 cultures (eutrophic - hyper-eutrphic conditions) favoured the growth of Roicosphenia, Navicula, Gomphonema, Aulacoseira, Cyclothela, Rhoalodia, Pseudostaurosira, Surrirella and Triblionella species. These species have been reported to grow on enhanced $\mathrm{NO}_{3}{ }^{2-}$ concentrations (Bellinger et al., 2006; Shinneman et al., 2016; Trobaja and Mann, 2019; Barinova et al., 2019; Zhang et al., 2020). It should be noted that diverse benthic epilithic diatom assemblages responded differently to controlled optimizations in nutrient concentrations. The diversity and abundance of benthic epilithic diatom species were influenced by the loadings of phosphate and nitrate in water (Shinneman et al., 2016; Moorhouse et al., 2018; Barinova et al., 2019; Trobaja and Mann, 2019; Zhang et al., 2020). At moderate $\mathrm{PO}_{4}{ }^{2-}$ and $\mathrm{NO}_{3}{ }^{2-}$ concentrations, benthic epilithic diatom assemblages displayed a wide of diversity. However, at higher concentrations there was reduction in the diversity in some of the diatom species. Our findings clearly indicates that benthic epilithic diatom assemblages are more dependent on phosphate than nitrates concentrations in a controlled environment. The result showed that diatoms growth were impacted by even reduced concentrations of phosphate compared to higher nitrate concentrations. These findings are in agreement with early works of Han et al. (2016) who reported that diatom cells have higher reflection on the concentrations of phosphate than nitrate. The data clearly demonstrates that optimization of $\mathrm{PO}_{4}{ }^{2-}$ and $\mathrm{NO}_{3}{ }^{2-}$ trophic levels on benthic epilithic diatom assemblage cultures could plausibly be employed in predicting of trophic status and water quality conditions of a surface freshwater impoundment. This is due to the fact that $\mathrm{PO}_{4}{ }^{2-}$ and $\mathrm{NO}_{3}{ }^{2-}$ concentrations are important variables which aid the growth of diatom assemblage cultures in aquatic ecosystems (Shinneman et al., 2016; Moorhouse et al., 2018; Barinova et al., 2019; Trobaja and Mann, 2019; Zhang et al., 2020).

\section{Conclusion}

In conclusion, the present study set out to investigate the controlled optimization of $\mathrm{PO}_{4}{ }^{2-}$ and $\mathrm{NO}_{3}{ }^{2-}$ concentrations in benthic epilithic diatom assemblage cultures in predicting the trophic status and water quality conditions of the Swartpruit River, North West Province, South Africa. The findings of the study has obviously revealed that monitoring the growth pattern of benthic epilithic diatom assemblage cultures in a controlled optimized $\mathrm{PO}_{4}{ }^{2-}$ and $\mathrm{NO}_{3}{ }^{2-}$ amounts growth media to ascertain taxonomic compositions and abundance of diatom culture can be used in predicting the trophic status and freshwater quality conditions of a freshwater ecosystem. The data presented in this study have highlighted the fact that the trophic status the trophic status and water quality conditions of a very important surface freshwater resource like the Swartspruit River, South Africa can be plausibly predicted by controlled optimization of $\mathrm{PO}_{4}{ }^{2-}$ and $\mathrm{NO}_{3}{ }^{2-}$ amounts in the growth media. The researchers are of the anticipation that the information 
presented in this report will be of precise significance to the Greater Haartebeesport Metropolitan Authorities, researchers and the general public concerning the risk assessments, health consequences and the seasonal occurrence and prevalence of pathogenic algal species in this very important drinking freshwater reservoir. Our findings have provided probable and useful insights to the risk that may be associated with the occurrence and prevalence of toxigenic benthic epilithic diatom assemblage blooms in this freshwater reservoir which is predominantly used for agricultural, domestic, industrial and recreational activities by the inhabitants of the Greater Haartebeesport Metropolitan Area in the North West Province, South Africa. We anticipate that the findings presented in this report can have a significant impact in integrating new knowledge with existing knowledge (if any) to gain a better insights into the state of water quality and safety around and downstream of this very important inland freshwater resource in South Africa.

Acknowledgements. The authors are grateful to the University of South Africa (UNISA) and the University of Johannesburg, South Africa for the financial support. We also thank the Agricultural Research Council-Institute for Soil, Climate and Water (ARC-ISCW), South Africa for their support.

\section{REFERENCES}

[1] Barinova, S., Bondarenko, A., Ryabushko, L., Kapranov, S. (2019): Microphytobenthos as an indicator of water quality and organic pollution in the western coastal zone of the Sea of Azov. - Oceanological and Hydrobiological Studies 48(2): 125-139.

[2] Bellinger, B. J., Cocquyt, C., O'reilly, C. M. (2006): Benthic diatoms as indicators of eutrophication in tropical streams. - Hydrobiologia 573(1): 75-87.

[3] Bere, T., Phiri, C., Kadye, W. T., Utete, B. (2013): Benthic diatom assemblages in mountain streams: community structure in relation to environmental and human pressures. - African journal of ecology 51(4): 625-634.

[4] Chia, A. M., Bako, S. P., Alonge, S., Adamu, A. K. (2011): Records of diatoms and physicochemical parameters of seasonal ponds in Zaria-Northern Nigeria. - West African Journal of Applied Ecology 18(1): 79-93.

[5] Della Bella, V., Puccinelli, C., Marcheggiani, S., Mancini, L. (2007): Benthic diatom communities and their relationship to water chemistry in wetlands of central Italy. International Journal of Limnology 43(2): 89-99.

[6] Desrosiers, C., Leflaive, J., Eulin, A., Ten-Hage, L. (2013): Bioindicators in marine waters: benthic diatoms as a tool to assess water quality from eutrophic to oligotrophic coastal ecosystems. - Ecological indicators 32: 25-34.

[7] Dong, X., Bennion, H., Maberly, S. C., Sayer, C. D., Simpson, G. L., Battarbee, R. W. (2012): Nutrients exert a stronger control than climate on recent diatom communities in Esthwaite Water: evidence from monitoring and palaeolimnological records. - Freshwater Biology 57(10): 2044-2056.

[8] Estifanos, T. K., Traunspurger, W., Peters, L. (2013): Selective feeding in nematodes: a stable isotope analysis of bacteria and algae as food sources for free-living nematodes. Nematology 15(1): 1-13.

[9] Garvetto, A., Nézan, E., Badis, Y., Bilien, G., Arce, P., Bresnan, E., Gachon, C. M., Siano, R. (2018): Novel widespread marine oomycetes parasitising diatoms, including the toxic genus Pseudo-nitzschia: genetic, morphological, and ecological characterisation. Frontiers in microbiology 9: 2918. 
[10] Gérin, S., Delhez, T., Corato, A., Remacle, C., Franck, F. (2020): A novel culture medium for freshwater diatoms promotes efficient photoautotrophic batch production of biomass, fucoxanthin, and eicosapentaenoic acid. - Journal of Applied Phycology 32: 1581-1596.

[11] Giles, J. (2005): Nitrogen study fertilizes fears of pollution. - Nature 433(7028): 791.

[12] Grobbelaar, J. U. (2003): Algal Nutrition-Mineral Nutrition. - In: Richmond, A. (ed.) Handbook of microalgal culture: Biotechnology and applied phycology. Blackwell Publishing Ltd., pp. 95-115.

[13] Han, L., Xu, B., Qi, F., Chen, Z. (2016): Effect of nitrogen/phosphorus concentration on algal organic matter generation of the diatom Nitzschia palea: Total indicators and spectroscopic characterization. - Journal of Environmental Sciences 47: 130-142.

[14] Harding, W. R., Archibald, C. G. M., Taylor, J. C. (2005): The relevance of diatoms for water quality assessment in South Africa: A position paper. - Water SA 31(1): 41.

[15] Klose, K., Cooper, S. D., Leydecker, A. D., Kreitler, J. (2012): Relationships among catchment land use and concentrations of nutrients, algae, and dissolved oxygen in a southern California river. - Freshwater Science 31(3): 908-927.

[16] Kociolek, P. J., Laslandes, B., Bennett, D., Thomas, E., Brady, M., Graeff, C. (2014): Diatoms of the United States 1. - Acta Botanica Hungarica 56: 3-4.

[17] Kwon, H. K., Oh, S. J., Yang, H. S. (2013): Growth and uptake kinetics of nitrate and phosphate by benthic microalgae for phytoremediation of eutrophic coastal sediments. Bioresource technology 129: 387-395.

[18] Lacerda, S. R., Koening, M. L., Neumann-Leitão, S., Flores-Montes, M. J. (2004): Phytoplankton nyctemeral variation at a tropical river estuary (Itamaracá-PernambucoBrazil). - Brazilian Journal of Biology 64(1): 81-94.

[19] Leelahakriengkrai, P., Peerapornpisal, Y. (2010): Diversity of Benthic diatoms and water quality of the Ping river, Northern Thailand. - Environ. Asia 3(1): 82-94.

[20] Leira, M., Sabater, S. (2005): Diatom assemblages distribution in catalan rivers, NE Spain, in relation to chemical and physiographical factors. - Water Research 39(1): 73-82.

[21] Leland, H. V., Porter, S. D. (2000): Distribution of benthic algae in the upper Illinois River basin in relation to geology and land use. - Freshwater Biology 44(2): 279-301.

[22] Lynn, S. G., Kilham, S. S., Kreeger, D. A., Interlandi, S. J. (2000): Effect of nutrient availability on the biochemical and elemental stoichiometry in the freshwater diatom Stephanodiscus minutulus (Bacillariophyceae). - Journal of Phycology 36(3): 510-522.

[23] Maria, T. F., De Troch, M., Vanaverbeke, J., Esteves, A. M., Vanreusel, A. (2011): Use of benthic vs planktonic organic matter by sandy-beach organisms: A food tracing experiment with 13C labelled diatoms. - Journal of Experimental Marine Biology and Ecology 407(2): 309-314.

[24] Mensah, P. K., Palmer, C. G., Muller, W. J. (2013): Derivation of South African water quality guidelines for Roundup ${ }^{\circledR}$ using species sensitivity distribution. - Ecotoxicology and Environmental Safety 96: 24-31.

[25] Moorhouse, H. L., Read, D. S., McGowan, S., Wagner, M., Roberts, C., Armstrong, L. K., Nicholls, D. J. E., Wickham, H. D., Hutchins, M. G., Bowes, M. J. (2018): Characterisation of a major phytoplankton bloom in the River Thames (UK) using flow cytometry and high performance liquid chromatography. - Science of the Total Environment 624: 366-376.

[26] Muhid, P., Davis, T. W., Bunn, S. E., Burford, M. A. (2013): Effects of inorganic nutrients in recycled water on freshwater phytoplankton biomass and composition. - Water research 47(1): 384-394.

[27] Poulíčková, A., Duchoslav, M., Dokulil, M. (2004): Littoral diatom assemblages as bioindicators of lake trophic status: A case study from perialpine lakes in Austria. European Journal of Phycology 39(2): 143-152.

[28] Salomoni, S. E., Rocha, O., Callegaro, V. L., Lobo, E. A. (2006): Epilithic diatoms as indicators of water quality in the Gravataí river, Rio Grande do Sul, Brazil. - Hydrobiologia 559(1): 233-246. 
[29] Shinneman, A. L., Umbanhowar, C. E., Edlund, M. B., Hobbs, W. O., Camill, P., Geiss, C. (2016): Diatom assemblages reveal regional-scale differences in lake responses to recent climate change at the boreal-tundra ecotone, Manitoba, Canada. - Journal of paleolimnology 56(4): 275-298.

[30] Taylor, J. C., Harding, W. R., Archibald, C. G. M. (2007): An illustrated guide to some common diatom species from South Africa. - Pretoria, Water Research Commission, 225p.

[31] Torres, M. A., Ritchie, R. J., Lilley, R., Grillet, C., Larkum, A. W. D. (2014): Measurement of photosynthesis and photosynthetic efficiency in two diatoms. - New Zealand journal of botany 52(1): 6-27.

[32] Trobajo, R., Mann, D. G. (2019): A rapid cleaning method for diatoms. - Diatom Research 34(2): 115-124.

[33] Walsh, G. W., Wepener, V. (2009): The influence of land use on water quality and diatom community structures in urban and agriculturally stressed rivers. - Water SA 35(5).

[34] Wear, E. K., Carlson, C. A., Windecker, L. A., Brzezinski, M. A. (2015): Roles of diatom nutrient stress and species identity in determining the short-and long-term bioavailability of diatom exudates to bacterioplankton. - Marine Chemistry 177: 335-348.

[35] Winter, J. G., Duthie, H. C. (2000): Epilithic diatoms as indicators of stream total N and total P concentration. - Journal of the North American Benthological Society 19(1): 32-49.

[36] Wong, S. W., Leung, K. M. (2014): Temperature-dependent toxicities of nano zinc oxide to marine diatom, amphipod and fish in relation to its aggregation size and ion dissolution. - Nanotoxicology 8(Sup1): 24-35.

[37] Zhang, J., Shu, X., Zhang, Y., Tan, X., Zhang, Q. (2020): The responses of epilithic algal community structure and function to light and nutrients and their linkages in subtropical rivers. - Hydrobiologia 847(3): 841-855.

[38] Zimmermann, J., Glöckner, G., Jahn, R., Enke, N., Gemeinholzer, B. (2015): Metabarcoding vs. morphological identification to assess diatom diversity in environmental studies. - Molecular Ecology Resources 15(3): 526-542. 